England and educated at the Manchester Grammar School and the University of Manchester. After graduating in chemistry, he did two years of research at Rothamsted, and then took his Ph.D. at London in 1927. Following a year of postdoctorate research at the Polytechnic Institute, Zurich, he was assistant lecturer in agricultural chemistry during 1928-36 in the University of Leeds, and then went to the University of Missouri, becoming professor of soils there in 1942. Prof. Marshall has been secretary. and chairman of the Colloid Chemistry Division of the American Chemical Society, and has served as president of the Soil Science Society of America and chairman of the Soils Division of the American Society of Agronomy.

\section{American Academy of Arts and Sciences}

Dr. EDWIN H. LAND has been elected president of the American Academy of Arts and Sciences in succession to Dr. H. M. Jones, professor of English, Harvard University. Dr. Land is the founder, president and director of research of the Polaroid Corporation, Cambridge, Mass., and is an inventor of polarizers, the Land camera that delivers a finished photograph immediately after exposure, and other optical equipment. $\mathrm{He}$ received the 1945 Rumford Gold and Silver Medals awarded by the Academy for his contributions in polarized light and photography. Vice-presidents of the four Classes of the Academy have been elected as follows: Class I (Matherriatical and Physical Sciences), Dr. Jerome C. Hunsaker, head of the Department of Aeronautical Engineering, Massachusetts Institute of Technology ; Class II (Natural and Physiological Sciences), Prof. Alfred S. Romer, Alexander Agassiz professor of zoology, Harvard University ; Class III (Social Arts), Erwin D. Canham, editor of the Christian Science Monitor; Class IV (Humanities), Wallace Goodrich, director emeritus, New England Conservatory of Music. The following have been elected foreign honorary members of the Academy : Class I (Section 3 , Chemistry), Sir Cyril Hinshelwood, professor of chemistry, University of Oxford ; Class II (Section 2, Botany), Prof. C. W. Wardlaw, professor of cryptogamic botany, University of Manchester ; Class II (Section 3, Zoology and Physiology), Sir Charles Harington, director of the National Institute for Medical Research, London; Class III (Section 2, Government, International Law and Diplomacy), Charles Habib Malik, Lebanese Minister to the United States, U.N. Delegate, educationist ; Class IV (Section 2, History, Archoeology and Anthropology), Prof. H. E. Sigerist, formerly professor of the history of medicine, Johns Hopkins University, and now living in Switzerland. The total membership of the Academy now numbers nearly a thousand, which is the permissible limit.

\section{A Century of Lighthouse Equipment: Chance} Brothers, Ltd.

ON June 6, a dinner held in London marked the centenary of the opening of the Lighthouse Works of Messrs. Chance Brothers. The firm began its existence in 1824, when Robert Lucas Chance acquired the works of the British Crown Glass Co. at Smethwick, and has continued there with members of the family at its head until the present day. Its history has been sketched in a well-illustrated brochure entitled "Mirror for Chance" recently issued. In 1839, James Timmins Chance, nephew of the founder, and a brilliant mathematician and scholar, joined the Com. pany, and his interest and knowledge were responsible for the beginning of the firm's long association with navigation lighting. In 1851, Chance's first lighthouse optic was shown at the Great Exhibition, and now in 1951 another Chance 'light' flashes from the Shot Tower in the South Bank Exhibition. Incidentally, the Smethwick works provided the million square feet of glass required to glaze the 'Crystal Palace' itself. Now the firm manufactures a wide range of laboratory, optical and other glasses, while a map showing the distribution all over the world of navigation lights equipped by Chance Brothers during the past hundred years is an impressive tribute to its contribution to safety at sea.

\section{Patent Office Library}

MANY readers will be interested to hear that arrangements have been made to keep the Patent Office Library open provisionally until 9 p.m. from Monday to Friday each woek. Saturday closing remains at 5 p.m. Evening hours of opening should be specially valuable to those occupied elsewhere during the day and to visitors to London. This is our leading national technical reference library ; until the First World War it was open from 10 a.m. until 10 p.m., had ample accommodation to give open access to.its whole contents, and provided many useful bibliographical guides, of which the class lists of periodicals will be specially remembered. Owing to the effect of two wars these facilities had been greatly curtailed. The Library has been closed at 6 p.m. on Monday to Friday and at 5 p.m. on Saturdays; binding has been in arrears, with consequent restrictions of access to many periodicals ; accessions have not kept pace with the large increase of publications and no recent bibliographies have been pub. lished. The prospect of an enlarged and modern Patent Office Library on a new site is therefore most encouraging; but in the meantime much might be done to restore the old standards of service, and make the whole contents of the Library more promptly available to readers.

\section{Journal of the Franklin Institute: 125th Anniversary} Issue

THE January 1951 issue of the Journal of the Franklin Institute is a special conmemorative issue to celebrate the 125th anniversary of the establishment of the Journal (pp. 208+xxxii ; Philadelphia, Pa. : Franklin Institute, 1951; 1 dollar). In accordance with the policy enunciated in its original prospectus in 1825, the Journal has remained an unspecialized technical publication. Its object was "to diffuse information on every subject connected with useful arts", and the content of its volumes during the past century and a quarter reveals the great material progress that has been made during that period, the transition from hand crafts to factory production, and, in particular, the growth of specialization and the quickening tempo of progress in science and technology during the past fifty years.

The anniversary issue contains a short introductory article by $\mathrm{T}$. Coulson outlining the history of the Journal, and then the remainder is devoted to "Science and Tomorrow", a group of fifteen papers describing possible and probable future developments in various branches of science and technology. The contributors are all leading authorities, and both students of science and laymen will find the contributions informative and interesting. In the first section, on the basic physical sciences, O. Struve 